\title{
THE IMPACTS OF POLITICAL REGIME AND GOVERNANCE ON GROWTH OF EAST AFRICAN ECONOMIES
}

\author{
Issa Moh'd Hemed \\ Department of Economics, Zanzibar University, Tanzania
}

DOI: https://doi.org/10.36713/epra3732

\begin{abstract}
This paper examines which type of political regime is appropriate to improve economic growth in East Africa by
investigates the relationship among governance, political regime and economic performance. The Fixed Effect Model
(FEM) is estimated using panel data cover the period from 1996 to 2017. The findings of this study show that all
indicators of governance have positive and significant impact on economic growth in East Africa. This result also
reveals that under the democratic system, the effectiveness of government has strong effect on economic growth more
than anocracy and autocracy. The coefficient of autocratic regime is negative and statistical significant which
indicates that the efforts undertaken by the government in this region cannot be helpful to enhance economic growth if
country is extremely relies on autocracy as this system weaken the proper allocation of the country's resources. This
study suggests that in order to have stable economic growth, the government should maintains peace and order, obeys the
rule of law and observe the human rights so as to minimize the authoritarian system, revive the democratic regime, and
improve the effectiveness of government towards remarkable economic growth and development in East Africa.
\end{abstract}
KEYWORDS: Political regime, governance, economic growth, East African countries.

\section{INTRODUCTION}

Political regime and governance have been among the hot discussing issues when come to explain the fundamental instruments of economic growth in African countries. As Malatesta., (1977) pointed out that, 'every economic question of some importance automatically becomes a political question'. Political regime refer to a "set of fundamental rules and procedures that govern the conduct of politics in a given political system" (Masime, K, \& Kibara, G,. 2003), while governance refers to the capacity of the authority to provide public services and its capability to intervene in economic sphere either to encourage or discourage the productive aspects through various agents of economy (Sen, Kulan, 2016). On the one hand, the undesirable political structure associated with poor fundamental rules applied by the political leaders discourage the investment opportunities and eventually decelerate the rapidity of economic growth. On the other hand, however, poor and disrepute governance may leads to social and political disorder and later hinder the growth of economic development.

Moreover, it is believing that, the political stability and good governance are the preliminary steps for economic growth and development in Africa.
However, many countries particularly in eastern Africa need economic transformation so as to cope with rapid increases of population, create the condition for good governance, maintain the political stability and create a competitive business environment that make Africa emerged in the global economy (ECA, 2013). The democratic progress that adopted in some countries of eastern Africa is only achieved after attaining substantive economic transformation (Donge, $\mathrm{K}$ et., al. 2012). Since the middle of 1990 s, most economies of Eastern Africa have been rapidly increasing due to stretch of democracy and emergence of new political leaders who work together with development partners whilst making sensible policies that favour the growth of economics (Steven Radelet, 2010). Besides, the presence of competitive free and fair elections also regards as a mixed blessings towards achievement of economic transformation that most of African prospered (Khan, M. 2012). Contrary, the incentives of political elites in poor region of Africa have been affected by democratisation, Alex, D,. (2012) indicates that the poor economic performance observed to some African countries whilst having good political system were the outcome of many politicians that are mostly 
restricted to use rents to build their alliances towards supporting the process of transformation.

Furthermore, in the region of East Africa countries, the issue of governance and political regime have been studied separately since 1960 s. The concern about why democratic governance in many countries fail to improve their economic growth is now raising. Poor Governance indicators like political instability, disobey the rule of law, violation of human rights and ineffectiveness of country's regulations are closely related with transitions of political regime. The abuse of power and extend the presidential term limit are also taken into consideration in the recent time as the sources of government failure in many East African countries (Bolorunduro, A., 2017). According to the World Governance Indicators (WGI) ranked the six indicators of governance on the ranges from -2.5 indicates poor governance to 2.5 measures the countries with well performed (WDI, 2019). The scores of these indicators show that, the region of East Africa have recorded with the lowest level of performance in terms of politics and governance. The fundamental reasons for bad politics and poor governance in these countries are the authoritarian regime where the system centralized in the hands of few people, violation of human rights and defy the rule of law that altogether hinder the proper utilization of social and economic resources that finally slow down the growth of economic development (Kpundeh, S, 1992).

Apart from that, at the end of cold war in 1990s, Eastern region of Africa has experienced in divergence of political transitions from autocratic regime to democratic authority (Way, Lucan. 2012a). In this transition, some nations shifted to representative governments that commonly adopt some features of democratic system, however the extreme power is still dominated in the hands of a single party while organization of the civil society, opposition parties and right of voting are strictly under siege and there is a little room to oversight the managerial behaviours of the ruling party (Siegle, J. 2006). Autocratic regime, is the political structure which the supreme power is dominated in the hand of single person or few group of people who has unlimited power. The Eritrea is among the countries in the region governed by the autocratic system. Although the huge transitions of political regime in this region took place, there are some other countries like Kenya, Comoros, Madagascar, Malawi, Mauritius and Burundi are retain with some features of democratic system, where the citizen have the constitutional rights to criticize and express their political views in the system. Meanwhile the countries like Tanzania, Zimbabwe, Mozambique, Rwanda and Uganda governed by anocracy system which mixed some features of democratic system and autocratic system (Polity IV, 2019).

Rest of the this paper is organized as follow, section two describes the theoretical and empirical review of the study. Where section three gives the methodology and data collection, section four discusses the analysis and interpretation of findings and finally in section five concluding remark and policy implications.

\section{LITERATURE REVIEW}

Although the views that governance may improves economic growth is logically an acceptable, it is reputedly poor in describing or predicting the various indicators of governance in relation to economic growth across various countries having different political structures. This reveals that both governance and economic growth have a close relationship in accordant with political system. Therefore, many scholars in the field of political economy started to debate about the best political structures that suited for governance to prosper the growth of economy. The key point of this debate is whether the democratic system, anocratic or autocratic play an important role to impact the economic growth in Eastern region of Africa (Sen, Kulan, 2016). However, the various empirical studies diverge into different opinions, one group "compatibility schools" supported the growth of economy is a product of political transitions that ending with establishment of democratic governance and finally improves growth (Rothstein, 2011). Early supportive empirical studies, revealed a clear positive and significant relationship between democracy and economic growth (Jalles, J. T. 2010). Under the system of democracy, it is being relatively easily to control the channels and loopholes of corruption (Alon, et. al., 2016). Some scholars demonstrates that high influence of political regime on economic growth is only attained if education and technology taken into consideration (Jamali, Kh et, al., 2007). It also plausibly suggested that the strength of democratic system to enhance economic growth relying on the level of intelligences where further plays a significant role to weaken the negative impact of political institutions (Salahodjaev (2015). Specifically it seems democratic regime highly influences economic growth in case of weak state capacity (Knutsen, H., 2013).

In spite of these conceivable arguments other group (conflict school) believed that democratic regimes do not matter towards promoting economic growth while mostly struggle to hold position in a government which eventually demolish sphere of economic prosperity particularly when country is at the immature stage of development. Moreover, this school believed that autocratic will mostly improve the economic growth due to efficient accumulation and distribution of resources. Finally group "skeptical school" concluded that the political regime have nothing to do with economic growth. Many studies support this argument based on showing that democratic regime have failed to indicate the direct relationship with economic growth but only pay the way for other factors such as capital accumulation, foreign direct investment, economic freedom and inflation to have an impact on growth (Doucouliagos \& Uluba, 2008, Bougharriou et.al, 2019). On other hand, in order to speedily attain economic growth; good governance should plays a pivot role to help better provision of useful economic resources (Kaufmann et 
al,.. 2002; Chaudhry et al,.. 2009). In turn attaining fast economic growth, the accountability, political stability, quality of regulation and the rule of law should be given more weight as they have critical chance to improve growth (Kamil, et, al. 2015). The significance of good governance have also supported the distribution of income and reduce poverty (Nguyen, $\mathrm{C}$ et, al. (2019), it also stimulates the growth of investment to education sectors and further support the growth of economy (Awan, R,. et al,. 2018). In particular, good governance and appropriate planning are considered as the vital instruments for growth, which further attract foreign investors in economy (Abdelbary, 2018).

Although, given the notable list of empirical studies that have examined the link among the political regime, governance and economic growth, the outcomes were not the same or did not end up with consensus and convincing solutions in most circumstances. Therefore this paper investigates the

$$
Y_{i t}=A_{i t} K_{i t}^{\alpha} L_{i t}^{\beta}
$$

Where $Y$ denotes as the value of output in economy, A is the technological progress, $\mathrm{K}$ is the stock of physical capital and $L$ stands as the stock of human capital. Where $\alpha$ and $\beta$ are the shares of output that goes to physical capital and human respectively. By

$$
\frac{\dot{Y}_{(t)}}{Y_{(t)}}=\alpha_{(t)} \frac{\dot{K}_{(t)}}{K_{(t)}}+\beta_{(t)} \frac{\dot{L}_{(t)}}{L_{(t)}}+\frac{\dot{A}_{(t)}}{A_{(t)}}
$$

To transform the equation into logarithmic form, the equation (3.2) above takes the $\log$ in both sides and expressed in the following simplified model

$$
\operatorname{In} \dot{Y}_{t}=\alpha \operatorname{In} \dot{K}_{t}+\beta \operatorname{In} \dot{L}_{t}+\operatorname{In} \dot{A}_{t}
$$

Where $\operatorname{In} \dot{Y}_{t}$ defines as a percentage change of output per time, $\alpha \operatorname{In} \dot{K}_{t}$ is the total percentage shares of output from the stock of physical, $\beta \operatorname{In} \dot{L}_{t}$ is the total percentage share of output that goes to Labour and In $\dot{A}_{t}$ denotes as a Solow residuals, that measures the

$$
\operatorname{In} \dot{A}_{t}=\alpha_{0}+\gamma \operatorname{In} \dot{X}_{t 1}+\operatorname{\delta in} \dot{X}_{t 2}+\varphi \operatorname{In} \dot{X}_{n k}
$$

Substituting $\operatorname{In} \dot{A}_{t}$ in Equation (3.3) from equation (3.4) and ordered to formulate the equation (3.5) which defined as:

$$
\operatorname{In} \dot{Y}_{t}=\alpha_{0}+\alpha \operatorname{In} \dot{K}_{t}+\beta \operatorname{In} \dot{L}_{t}+\gamma \operatorname{In} X_{t 1}+\delta \operatorname{In} \dot{X}_{t 2}+\varphi \operatorname{In} n k
$$

\subsection{Model Specification}

The study adopted and modified an econometric model employed by Joseph A,. at.al,. (2016) and incorporated variables applied by Liew, C. et al,. (2012) relied on the Solow growth model. The econometrics techniques of analysis is supported by dynamic panel regression technique which incorporated both time series and cross sectional components. The general econometric model to be regressed can be:-

$$
\text { InGDPrate }_{i t}=\beta_{0}+\beta_{1} K_{i t}+\beta_{2} L_{i t}+\beta_{3} F D I_{i t}+\beta_{4} G O V_{i t}+\alpha_{4} \dot{P R} R_{i t}+\varepsilon_{i t}
$$

Ingprate denotes as percentage growth rate of real GDP per capital, $\mathrm{K}$ is the percentage of gross fixed capital formation, L denotes as annual percentage of population growth rate, FDI stands as the inflow of 
Foreign Direct Investment, GOV denotes as the governance, that comprised different indicators of governance, PR stands as dummy variable for political regimes, $\beta \mathrm{j}, \mathrm{j}=1,2$, ... are parameters to be estimated, $i$ denote cross countries in the study, t denotes time series and $\varepsilon=$ random error term, definition of each term.

\subsection{Sample of Countries in the Study}

This study includes the sample of 12 east African countries (Tanzania, Kenya, Uganda, Rwanda, Burundi, Malawi, Mozambique, Madagascar, Zimbabwe, Comoros, Mauritius and Eritrea) cover the annual period from 1996 to 2017. Djibouti, Ethiopia, Somalia, Zambia, Seychelles, Reunion and Mayotte are also countries in East African block but excluded from the study due to unavailability of data on some of studying variables.

\subsection{Definition and Measurement of variables.}

The key constructs in this study are economic growth, regime types and governance indicators, many previous studies have succeed to applying these constructs that are well constructive and mostly used. Referring to previous works, this study applied these constructs and control variables as follows: rgdprate is a dependent variable and denotes to the percentage growth of real GDP per capital. Other basic instruments of economic growth included in this model as the control variables. Labour (L) denotes to estimate the economic value of workers in production process, this variable is also regarded to be the traditional determinants in the 'endogenous growth theories' postulate by Lucas (1988) and Romer D (2012). It is proxed as annual percentage growth of the country's population (Tinbergen, 1959). Capital (K) is also used as a control variables to measure the contribution of physical investment to economic growth. It is proxed as percentage of 'Gross fixed capital formation (GCF)' to GDP. The positive coefficients are expected, as greater contributions of human and physical capital will bring positive effects to growth of economy (Iheonu C, et.al (2017). The selection of these determinants are relied on previous multifarious growth theories (see for instance Romer. $\mathrm{D}, 2012)$. Another control variable used in this study is FDI denoted as annual percentage of inward flow of investment from outside the country. In an economy, the higher the inflow of this investment, the higher the rate of economic growth. Moreover, to estimate the impact of governance to economic growth, this study also utilize the six world governance indicators obtained from World bank (WB) relating to the decisive work by Kaufmann et al,.., (2005) and Jilenga \& Helian, (2017). These indicators given the values ordering from negative 2.5 denotes poor quality of governance to positive 2.5 signifies better quality of governance. These determinants include; Rule of Law (RL), Regulatory Quality (RQ), Voice and Accountability (VA), Control of Corruption (CC), Government Effectiveness (GE) and Political Stability (PS). Furthermore, this study also involved the determinants of political regime.

Table 2. Summary of Variables and Source

\begin{tabular}{|c|c|c|c|}
\hline Variable & Variable Description & Previous Author & Sources \\
\hline InRGDPrate & Growth rate of real GDP per capita & Awan R et al,.., (2018) & UNCTAD, 2019 \\
\hline POPrate & $\begin{array}{l}\text { The annual percentage of population } \\
\text { growth rate from } 1996 \text { to } 2017\end{array}$ & Salahodjaev (2015) & WDI, 2019 \\
\hline GFCFrate & $\begin{array}{l}\text { The Percentage of Gross Fixed Capital } \\
\text { Formation from } 1996 \text { to } 2017\end{array}$ & Iheonu C, et.al (2017) & WDI, 2019 \\
\hline FDI & $\begin{array}{l}\text { The inflow of Foreign Direct } \\
\text { Investment in \% of GDP from } 1996 \text { to } \\
2017\end{array}$ & Iheonu C, et.al (2017) & UNCTAD, 2019 \\
\hline GOV & $\begin{array}{l}\text { Comprised of six indicators to measure } \\
\text { the quality of governance }(-2.5 \text { to }+2.5)\end{array}$ & Jilenga \&Helian,2017 & \\
\hline PR & $\begin{array}{l}\text { The variable of Political Regime, coded } \\
\text { as the dummy variables from scores of } \\
\text { polity } 2 \text {. If Democracy }=1 \text {, Otherwise } 0 \\
\text { If Anocracy }=1 \text {, Otherwise } 0 \\
\text { If Autocracy }=1 \text {, Otherwise } 0\end{array}$ & Alon, Li \& Wu, (2016) & $\begin{array}{l}\text { Polity IV Project, } \\
\text { Characteristics of } \\
\text { political regime and } \\
\text { transitions,2019 }\end{array}$ \\
\hline
\end{tabular}

Source: Authors Compilation

Therefore, Anocracy, autocracy and democracy coded as the dummy variables from the score of polity 2 in the Polity IV project. That covered the characteristics of political regime and political transitions from 1800 to 2017 . The polity 2 score ranks from +10 (fully democracy) to -10 (consolidated monarchy) (Marshall, M. G,. et,. al., 2018). This project also groups the different countries into autocracy (polity 2 ranges from -10 to -6$)$, Anocracy (5 to 5 ) and Democracy (6 to 10). In this study, we codes democracy equal to 1 if the polity 2 score is greater than 5, otherwise is zero, Anocracy codes the value of 1 if the polity 2 score ranges between -5 and +5 , otherwise it takes the value of 0 , In the same manner Autocracy took the value of 1 if the polity 2 scores ranges from -6 to -10 , otherwise takes the value of zero. In order to avoid inclusion of perfect collonearity variables the variable of democracy will be treated as the dummy based group. 


\subsection{Estimation Technique}

To examine the impact of political regime, governance and economic growth in East African countries, this study employs the estimate technique of panel data because of its significant advantage compared with time-series and cross-sectional data sets run separately. This econometric techniques generate the degree of freedom with highest value while reduce the multicollineary problem leading to the best efficient estimates (Hsiao, 2013) and allow to control for individual effects (Hausman, 1981). This study compare between POLS Effect Model, FEM and REM and finally chooses the appropriate estimator for the

$$
\begin{gathered}
y_{i t}=\beta^{\prime} x_{i t}+\alpha_{i}+u_{i t} \text { with } u_{i t}=\mu_{i}+v_{i t} \text { where } i=1,2, . . \mathrm{N} ; \mathrm{t}=1,2, . . \mathrm{T} \\
y_{i t}=\beta^{\prime} x_{i t}+\alpha_{i}+\left(\mu_{i}+v_{i t}\right)
\end{gathered}
$$

Where $t$ is the time dimension, and $i$ the individual dimension. Therefore, $y_{i t}$ is the dependent variable of individual $i$ and time $t, X_{i t}$ is the value of explanatory variable $i$ at time $t, \beta$ is a vector of estimation coefficients, $\alpha_{i}$ is an unobserved individual-specific, time invariant intercepts, and $u_{i t}$, is the stochastic error term that varying across countries and/or times that comprise the value of $\mu_{i}$ which measures between

$$
y_{i t}=\beta_{1} x_{i t}+\alpha_{i}+u_{i t}
$$

However FEM leads the estimated coefficient $\beta_{l}$ (between estimator) to be biased and inconsistency when one or more coefficients correlated with $\alpha_{i}$ and is known as 'fixed unobserved components' (Jirata M, et. at, 2012). Correlation with 'fixed unobserved

$$
\bar{y}_{i}=\bar{x}_{i} \beta_{1}+\bar{\alpha}_{i}+\bar{u}_{i}, i=1, \ldots . N
$$

components' can be tolerated as it can be eliminated by within transformation process. To reduce the $\alpha_{i}$ therefore, average the equation (3.9) over time for each item and obtain the cross section equation:

By subtracting the equation (3.10) from equation (3.9) for each $i$ will eliminate $\alpha_{i}$ and obtain 'fixed effects transformed equation' (Jirata M, et. at, 2012)

$$
\left(y_{i t}-\bar{y}_{i t}\right)=\left(x_{i t}-\bar{x}_{i t}\right)^{\prime} \beta_{1}+\left(u_{i t}-\bar{u}_{i t}\right)-\ddot{y}_{i t}=\ddot{x}_{i t} \beta_{1}+\ddot{u}_{i t}, i=1, \ldots . N, \mathrm{t}=1, \ldots, \ldots T(3.11)
$$

By taking first differentiation from equation 3.8 it manages to demeaned the time-invariant effects by eliminating the individual effects $\alpha_{i}$. Therefore, the equation 3.11 can be naturally estimated by Ordinary Least Square (OLS) if $\ddot{x}_{i t}$ is strictly exogenous. This algebraic process is often called as within transformation, and the coefficient estimator obtain from equation is known as within estimator. Therefore within estimator will be consistent and unbiased when an explanatory variables are uncorrelated with distribution of $u_{i t}$ otherwise it will lead to endogenous problem. To validate the most appropriate model to describe the results of this study, it is important to check the suitableness of one model against others model. In order to compare the estimators of POLS and REM, this study employs Breusch-Pagan Lagrange Multiplier (BPLM) statistic. If the result rejects the null hypothesis meaning that the REM is the best model to generate the outputs. On the other hand, the best model between FEM and REM the Hausman test should be estimated. FEM will be an appropriate if reject the null hypothesis of Random Effect. Moreover the redundant fixed effect like hood technique is also undertaken to evaluate whether FEM is redundant or not.

\section{RESULTS AND DISCUSSIONS \\ 4.1 Pair wise Correlation Analyses}

The correlation matrix for 13 variables used in the study are indicated in table 4.1. The variables of six governance indicators started from government effectiveness, control of corruption, political stability, regulatory quality, Rule of Law and; Voice and Accountability are statistically significant and have positive correlation with real GDP per capita as expected. Among the governance indicators, Regulatory Quality is highly correlated with RGDP while the lowest value of correlation is revealed in the 
indicator of Voice and accountability. Moreover, the variables of political structures indicate that all regimes except autocratic are positively related with GDP as anticipated. However, the variable of regulatory quality has the highly correlated (0.866) with government effectiveness to almost out of all variables used in this study. In order to ruling out the highly multicollineary problem, this study will be estimated separately in the different regression models.

Table 4.1 Variables Description and Summary Statistics

\begin{tabular}{|c|c|c|c|c|c|c|c|c|}
\hline & & $\mathbf{1}$ & $\mathbf{2}$ & $\mathbf{3}$ & $\mathbf{4}$ & $\mathbf{5}$ & $\mathbf{6}$ & $\mathbf{7}$ \\
\hline 1 & Rgdp & 1 & & & & & & \\
\hline 2 & Capital & $\mathbf{0 . 1 8 5}$ & 1 & & & & & \\
\hline 3 & Labour & 0.005 & 0.102 & 1 & & & & \\
\hline 4 & FDI & $\mathbf{0 . 1 1 1}$ & $\mathbf{0 . 5 5 1}$ & 0.070 & 1 & & & \\
\hline 5 & Government effective & $\mathbf{0 . 2 4 7}$ & $\mathbf{0 . 2 3 6}$ & $\mathbf{- 0 . 2 6 1}$ & 0.050 & 1 & & \\
\hline 6 & Corruption Control & $\mathbf{0 . 1 8 4}$ & $\mathbf{0 . 2 7 1}$ & $\mathbf{- 0 . 3 1 2}$ & 0.085 & $\mathbf{0 . 6 7 0}$ & 1 & \\
\hline 7 & Political Stability & $\mathbf{0 . 2 1 3}$ & $\mathbf{0 . 1 8 3}$ & $\mathbf{- 0 . 3 3 7}$ & 0.103 & $\mathbf{0 . 5 8 5}$ & $\mathbf{0 . 5 6 3}$ & 1 \\
\hline 8 & Regulatory Quality & $\mathbf{0 . 2 5 0}$ & $\mathbf{0 . 3 5 7}$ & -0.096 & $\mathbf{0 . 1 2 4}$ & $\mathbf{0 . 8 6 6}$ & $\mathbf{0 . 5 6 7}$ & $\mathbf{0 . 4 9 0}$ \\
\hline 9 & Rule of Law & $\mathbf{0 . 2 3 0}$ & $\mathbf{0 . 2 9 6}$ & $\mathbf{- 0 . 3 0 8}$ & 0.023 & $\mathbf{0 . 8 5 5}$ & $\mathbf{0 . 7 3 3}$ & $\mathbf{0 . 7 0 5}$ \\
\hline 10 & Voice, Accountability & $\mathbf{0 . 1 8 2}$ & $\mathbf{0 . 1 9 7}$ & $\mathbf{- 0 . 2 1 9}$ & 0.053 & $\mathbf{0 . 6 4 2}$ & $\mathbf{0 . 3 6 2}$ & $\mathbf{0 . 6 4 7}$ \\
\hline 11 & Anocracy & 0.032 & $\mathbf{0 . 1 1 3}$ & $\mathbf{0 . 1 5 0}$ & $\mathbf{0 . 2 0 2}$ & -0.10 & $\mathbf{- 0 . 2 4}$ & $\mathbf{- 0 . 2 3}$ \\
\hline 12 & Autocracy & -0.059 & -0.021 & 0.085 & -0.02 & -0.09 & $\mathbf{0 . 1 9 1}$ & -0.03 \\
\hline 13 & Democracy & 0.003 & -0.096 & $\mathbf{- 0 . 2 1 3}$ & $-\mathbf{0 . 1 9}$ & $\mathbf{0 . 1 9 1}$ & $\mathbf{0 . 1 2 7}$ & $\mathbf{0 . 2 7}$ \\
\hline & & $\mathbf{7}$ & $\mathbf{8}$ & $\mathbf{9}$ & $\mathbf{1 0}$ & $\mathbf{1 1}$ & $\mathbf{1 2}$ & $\mathbf{1 3}$ \\
\hline 8 & Regulatory Quality & $\mathbf{0 . 4 9 0}$ & 1 & & & & & \\
\hline 9 & Rule of Law & $\mathbf{0 . 7 0 5}$ & $\mathbf{0 . 8 4 3}$ & 1 & & & & \\
\hline 10 & Voice, Accountability & $\mathbf{0 . 6 4 7}$ & $\mathbf{0 . 7 4 6}$ & $\mathbf{0 . 7 7 2}$ & 1 & & & \\
\hline 11 & Anocracy & $\mathbf{- 0 . 2 3 4}$ & -0.045 & $\mathbf{- 0 . 2 5 0}$ & $\mathbf{- 0 . 2 4}$ & 1 & & \\
\hline 12 & Autocracy & -0.030 & $\mathbf{- 0 . 2 8 3}$ & $\mathbf{- 0 . 1 5 5}$ & $\mathbf{- 0 . 4 4}$ & $\mathbf{- 0 . 4 0}$ & 1 & \\
\hline 13 & Democracy & $\mathbf{0 . 2 7 1}$ & $\mathbf{0 . 2 6 3}$ & $\mathbf{0 . 3 8 4}$ & $\mathbf{0 . 5 8 2}$ & $\mathbf{- 0 . 7 5}$ & $\mathbf{- 0 . 2 7}$ & 1 \\
\hline
\end{tabular}

The bold and Italic Indicate the significant correlation.

Source: Author's own calculation

\subsection{Descriptive Statistic;}

The summary description of statistics for all 13 variables used in the study from 1996 to 2017 are shown in table 4.2. The overall mean score of real GDP per Capita in the region of East Africa is 1.89 . The maximum value reach at 23.02 while the minimum value maintains to -19.05 . The score of Governance indicators in this region range from 1.12 as the maximum value to -2.52 as the minimum value while the maximum values of average score for political structures is reached in Anocracy structure (0.524) followed by Democracy (0.342) and Autocracy (0.129). The overall values of standard deviations as indicate how well the data disperse from the mean are also indicate in table 4.1 .

Table 4.2 Summary Statistics

\begin{tabular}{lllllll}
\hline & Variable & Observations & Mean & SD & Max & Min \\
\hline 1 & Rgdp & 286 & 1.89 & 4.406 & 23.02 & -19.05 \\
2 & Capital & 286 & 19.413 & 9.345 & 60.018 & 2.001 \\
3 & Labour & 286 & 2.576 & 0.931 & 7.917 & 0.069 \\
4 & FDI & 286 & 3.591 & 5.835 & 38.54 & -0.53 \\
5 & Government effective & 286 & -0.65 & 0.591 & 1.049 & -1.77 \\
6 & Corruption Control & 286 & -0.57 & 0.495 & 0.806 & -1.45 \\
7 & Political Stability & 286 & -0.51 & 0.748 & 1.12 & -2.52 \\
8 & Regulatory Quality & 286 & -0.633 & 0.697 & 1.127 & -2.243 \\
9 & Rule of Law & 286 & -0.62 & 0.607 & 1.077 & -1.85 \\
10 & Voice, Accountability & 286 & -0.60 & 0.693 & 1.007 & -2.22 \\
11 & Anocracy & 286 & 0.524 & 0.500 & 1.000 & 0.000 \\
12 & Autocracy & 286 & 0.129 & 0.336 & 1.000 & 0.000 \\
13 & Democracy & 286 & 0.342 & 0.475 & 1.000 & 0.000 \\
\hline Source: & Author's own calculation & & & & &
\end{tabular}

\subsection{Empirical results;}

The results of six regression models that examine the impact of governance and political regime on economic growth in selected East African countries are shown in panel A and B of table 2. In All six models, the percentage change of real GDP per capita is used as a dependent variable, while all independent variables except governance indicators are held constant in all models. The variable of labour, FDI and capital are incorporated as the control variables while 
anocracy and autocracy (the base regime is democracy) are applied as the variables of interest. Where each model, contains one measurement of governance indicators as an explanatory variable. The next step is to select an appropriate model for estimation, the Breusch-Pagan LM (BPLM) test, the Hausman and Redundant FE tests are performed and the outcomes of these specification tests are shown in table 4 (Panel A \& B). The results of BPLM test reject the null hypothesis that supporting the POLS effects model in favour of REM at one percent level of significant. The Hausman test in all six models indicate that the null hypotheses of REM is rejected as the probability value is highly significant at one percent level and in favour of FEM as an appropriate model. The results of Redundant FE like-hood test was also weighted to indicate that, the FEM is the best model and does not suffer with redundant effects as the p-value of Fstatistics is less than 1 percent level of significant. Therefore, both of these tests support the FEM as the best model to estimate the relationship between governance, political regime and economic growth in East Africa.

The results of the three models shown in Table 2 (Panel A) reveal that all six governance indicators are positive and statistically significant on growth ceteris paribus. In first model the government effectiveness has been estimated on economic growth, the results of this model revealed that the coefficient of governance is statistical significant at 5 percent. The negative sign and statistical significant of autocratic regime indicate that although the government put more efforts to improve the economic growth but under the autocratic system the speed of economic growth will be decelerate as the system weaken the proper accumulation and allocation of the country's resources. The control of corruption as regressed on growth rate of GDP per capita in the second model, reveals that the coefficient of control of corruption has positive and statistically significant associated with economic growth. This results implying that good political system integrated with democracy as well as strong prevention of corruption provide conducive environment to enhances economic growth. In the third model, the variable of Political Stability is estimated to examine its impact on economic growth. The findings of this model depict that the higher the rate of political stability with other thing held constant the higher the rate of economic growth.

Table 2.Multiple Regressions on Economic Growth (Panel A) Dependent Variable: InRGDP_PC_growth

\begin{tabular}{l|l|l|l}
\hline Models & Model 1 & Model 2 & Model 3 \\
\hline Governance Measure & Government effective & Corruption Control & Political Stability \\
\hline Constant & Fixed Effect & Fixed Effects & Fixed Effects \\
\hline Labour & $6.1831^{* * *}$ & $6.3759^{* * *}$ & $6.1454^{* * *}$ \\
& {$[55.296]$} & {$[58.611]$} & {$[87.764]$} \\
\hline Capital & $-0.0325^{* *}$ & $-0.0399^{* *}$ & $-0.0418^{* * *}$ \\
& {$[-1.913]$} & {$[-2.147]$} & {$[-3.275]$} \\
\hline FDI & $0.0078^{* * *}$ & $0.0084^{* * *}$ & $0.0073^{* * *}$ \\
& {$[4.935]$} & {$[10.39]$} & {$[6.508]$} \\
\hline Anocracy & $0.0068^{* *}$ & $0.0051^{*}$ & $0.0036^{* *}$ \\
& {$[2.015]$} & {$[1.779]$} & {$[1.928]$} \\
\hline Autocracy & -0.0091 & -0.0156 & 0.0136 \\
& {$[-0.487]$} & {$[-1.018]$} & {$[0.747]$} \\
\hline Governance & $-0.1336^{* *}$ & $-0.0912^{* *}$ & $-0.1024^{* *}$ \\
& {$[-2.416]$} & {$[-2.246]$} & {$[-2.312]$} \\
\hline Observations & $3.1108^{* * *}$ & $0.0549^{*}$ & $0.1179^{* * *}$ \\
\hline R & {$[3.825]$} & {$[1.750]$} & {$[6.4563]$} \\
\hline BPLM test & 286 & 286 & 286 \\
\hline Hausman Test & 0.9654 & 0.9642 & 0.9755 \\
\hline Redundant FE (F)Tests & $1082.122^{* * *}$ & $1060.309^{* * *}$ & $1153.315^{* * *}$ \\
\hline p $0.1 ; * 20.050^{* * *}$ & $31.5868^{* * *}$ & $27.6698^{* * *}$ \\
\hline & $29.80700^{* * *}$ & $255.5397^{* * *}$ & $421.7362^{* * *}$ \\
\hline
\end{tabular}

${ }^{*} \mathrm{p}<0.1 ;{ }^{* *} \mathrm{p}<0.05 ;{ }^{* * *} \mathrm{p}<0.01$; (all1-tailed).B:

The results of last three models presented in Table 4 (Panel B) reveal that the variable of Regulatory Quality regressed on growth in model 4 and Voice and Accountability in model 6 are positive and statistical significant at 1 percent level. However the results of fifth model as the Rule of Law regressed 
on RGDPGR per capita depicts that, the rule of law is not the main determinant of economic growth in selected East African countries. The coefficients of Anocracy and Autocracy are all negative in all six estimated models, this reveal that the democratic system have the highest influence to advance economic growth. Moreover, the results of political structures depict that the autocratic system emerge to have higher negative economic effects on growth rate than Anocracy, It's similar results with Alon, I,. et al,.,. (2016). On other side, all control variables excluded the variable of human capital are positive and statistical significant. Human capital have viewing a higher but negative contribution to Real GDP per capita, this results is similar with Oraye, J,.\& Mose G, (2016). As revealed in Table 4 (Panel A \& B), the coefficient of government effectiveness seemed to have highly influence on economic growth in all six models, This result is similar with the study of Awan, $\mathrm{R}$,.et al,. (2018). Moreover, the variable of Autocracy is negative in all six models and highly significant, showing that autocratic regimes lower the rate of economic growth than democratic systems in the region, it is corroborated with Alon, I,. et al,. (2016).

Table 4.Multiple Regressions on Economic Growth (Panel B) Dependent Variable: InRGDP_PC_growth

\begin{tabular}{l|l|l|l}
\hline Models & Model 4 & Model 5 & Model 6 \\
\hline Governance Measure & Regulatory Quality & Rule of Law & Voice Accountability \\
\hline & Fixed Effect & Fixed Effects & Fixed Effects \\
\hline Constant & $6.15384^{* * *}$ & $6.0097^{* * *}$ & $5.9296^{* * *}$ \\
& {$[56.3206]$} & {$[-1.6791]$} & {$[34.980]$} \\
\hline Labour & $-0.0300^{* *}$ & $-0.0220^{*}$ & $-0.0437^{* * *}$ \\
& {$[-1.9038]$} & {$[-1.6791]$} & {$[-3.1091]$} \\
\hline Capital & $0.00675^{* * *}$ & $0.0061^{* * *}$ & $0.0061^{* * *}$ \\
& {$[7.2930]$} & {$[6.8903]$} & {$[5.4305]$} \\
\hline FDI & $0.0060^{* *}$ & $0.0073^{* *}$ & $0.0075^{* *}$ \\
& {$[2.0009]$} & {$[2.4018]$} & {$[0.0158]$} \\
\hline Anocracy & -0.0182 & 0.0145 & $0.0659^{* *}$ \\
& {$[-1.1906]$} & {$[0.7820]$} & {$[1.9432]$} \\
\hline Autocracy & $-0.1450^{* * *}$ & $-0.1250^{* * *}$ & $-0.0699^{*}$ \\
& {$[-3.2829]$} & {$[-3.8278]$} & {$[-1.7195]$} \\
\hline Governance & $0.12845^{* * *}$ & 0.1989 & $0.2069^{* * *}$ \\
& {$[3.9079]$} & {$[5.8750]$} & {$[3.8853]$} \\
\hline Observations & 286 & 286 & 286 \\
\hline $\mathbf{R}^{2}$ & 0.9658 & 0.9669 & 0.9663 \\
\hline BPLM test & $1013.019^{* * *}$ & $1013.019^{* * *}$ & $1084.707^{* * *}$ \\
\hline Hausman Test & $30.355587^{* * *}$ & $28.3528^{* * *}$ & $30.9648^{* * *}$ \\
\hline Redundant FE (F)Tests & $243.583^{* * *}$ & $241.9165^{* * *}$ & $218.0322^{* * *}$ \\
\hline
\end{tabular}

${ }^{*} \mathrm{p}<0.1 ;{ }^{* *} \mathrm{p}<0.05 ;{ }^{* * *} \mathrm{p}<0.01 ;$ (all1-tailed).B:

\section{CONCLUSION AND POLICY IMPLICATION}

The overall results of this study enlighten the importance of involving the political regime and governance into economic growth theory. The countries under diverse of political system and different scores of governance indicators have different growth rate of economy. This study applied the FEM to examine the impact of governance and political regime to economic growth in East African countries. In order to fulfil this objective, this study incorporate six indicators of governance and 3 forms of political regime include anocracy, democracy and autocracy into the models. The results of this study demonstrate that all governance indicators have positive effects to economic growth. The results of political regime reveal that the transitions of political structure from democratic system to autocratic system, tend to lower economic growth. At the same time the effectiveness of governance to provide public goods may undermined by the unfriendly political regime and thus weaken the speed of economic growth. Therefore, the democratic system is more suitable for the governance to improve the speed of economic growth more than it can be improved under autocratic regime. Moreover, the government of East African countries should keep peace and security; and maintain political stability to attract more foreign investors to invest in various sectors of economy. The policy and peace markers should ensure obeying the rule of law and observe the human rights in order to revive the democratic regime, minimizing the authoritarian system and improve effectiveness of government towards remarkable economic growth and sustainable development.

\section{REFERENCE}

1. Abdelbary, I. (2018). Governance Matters and Economic Growth: Beyond the Egyptian Revolution. Theoretical Economics Letters, 8(4), 741-754. https://doi.org/10.4236/tel.2018.84051 
2. Alex Ducan et, al,. (2012). "What can political economists tell us about Africa, aid and development?"Africa Power and Politics, wrw.institutions-Africa.org

3. Alon I, Li Shaomin and Wu Jun. (2016)."Corruption, Regime Type, and Economic Growth", Public Finance and Management ISSN 1523-9721 Volume 16, Number 4, pp. 332-361.

4. Awan, R,. Akhtar, T,. Rahim, S. Sher, F,. E Cheema A,. (2018)."Governance, corruption and economic growth: a panel data analysis of selected SAARC countries" Pakistan economic AND social review volume 56, no. 1 .

5. Bolorunduro, A. (2017). "Governance and Economic Growth in Africa: Is Democracy Dead?" Rchtopic.com, available at https://richtopia.com/globaleconomics/governance-and-economic-growth-inafrica-is-democracy-dead

6. Bougharriou, N., Benayed, $W$., छ Gabsi, F. B. (2019). The democracy and economic growth nexus: Do FDI and government spending matter? Evidence from the Arab world. Economics: The Open-Access, OpenAssessment E-Journal. https://doi.org/10.5018/economics-ejournal.ja.201919

7. Chaudhry, I. S., Malik, S., Khan, K. N., \& Rasool, S. (2009). Factors affecting good governance in Pakistan: An empirical analysis. European Journal of Scientific Research, 35(3), 337-346.

8. Donge, $K$ et al,..,(2012)"Tracking Development in Southeast Asia and Sub-Saharan Africa: the primacy of policy" DOI: 10.1111/j.1467-7679.2012.00563.x Repec.

9. Doucouliagos, H., छ Ulubaşoğlu, M. A. (2008). Democracy and Economic Growth: A Meta-Analysis. American Journal of Political Science, 52(1), 61-83.

10. ECA, (2013). "Towards High Quality Growth and Structural Transformation in the Eastern Africa" United Nations Economic Commission for Africa (UNECA) Conference of African Ministers, Kigali.

11. Iheonu, $C$,. Ihedimma $G$,. \& Onweanaku $C$, (2017)."Institutional Quality and Economic Performance in West Africa". Munich Personal repec Archive.

12. Jalles, J. T. (2010). Does democracy foster or hinder growth? Extreme-type political regimes in a large panel. Economics Bulletin, 30(2), 1359-1372.

13. Jamali, Kh. Wandschneider, K,. \& Wunnava, Ph, (2007). "The effect of Political Regimes and technology on Economic Growth", Routledge, Taylor $\Theta^{2}$ Francis group, USA.

14. Jilenga,T,. \& Helinan, Xu,. (2017)."Institutional Quality and Economic growth in East African economies". Turkish Economic Review.

15. Jirata, M,. Chelule, J,. \& Odhiambo, $R$, (2012)."Deriving Some estimators of Panel Data Regression Models with Individual effects" International Journal of science and research (IJSR).

16. Kamil Omoteso, Hakeem Ishola Mobolaji., (2014). "Corruption, governance and economic growth in SubSaharan Africa: a need for the prioritisation of reform policies", Social Responsibility Journal, Vol. 10 ISSN: 2, pp.316-330, DOI 10.1108/SRJ-06-2012-0067.

17. Kaufmann, D., \& Kraay, A. (2002). "Growth without governance". World Bank Policy Research (Working Paper No. 2928). The World Bank.

18. Kaufmann, D., Kraay A., \& Mastruzzi M., (2005). "Governance matters IV: Governance indicators for 1996 - 2004". World Bank Policy Research Working
Paper, No.3630. Washington, D.C. DOI. 10.1596/1813-9450-3630

19. Knutsen, C. H. (2013). Democracy, State Capacity, and Economic Growth. World Development, 43, 1-18. https://doi.org/10.1016/j.worlddev.2012.10.014

20. Kpundeh, S. (1992). "Democratization in Africa; African views, African Voices", Panel on issues in Democratization Commission on behavioural and Social Sciences and Education, national Research Council, Washington, USA.

21. Malatesta, E., (1977). "Errico Malatesta: His life and Ideas". USA: Freedom Press.

22. Marshall, M. G,. Gurr T. R,. \& Jaggers, K, (2018)."Polity IV Project, Political Regime characteristics and Transitions, 1800-2017", Dataset Users' Manual, Centre for Systemic Peace.

23. Masime, K,. \& Kbara, G,. (2003)."Regime transitions and the Institutionalization of Democracy in Kenya: The December 2002 Elections and Beyond", The East African Journal of Human Rights, EAJHRD Vol. I No.1 2003 pp.13-29 ISSN 1686-900X, Kenya

24. Mengistu, A. A., छे Adhikary, B. K. (2011). Does good governance matter for FDI inflows? Evidence from Asian economies. Asia Pacific Business Review, 17(3), 281-299. https://doi.org/10.1080/13602381003755765

25. Nguyen, C. V., Giang, L. T., Tran, A. N., छ Do, H. T. (2019). Do Good Governance and Public Administration Improve Economic Growth and Poverty Reduction? The Case of Vietnam. International Public Management Journal, 1-27. https://doi.org/10.1080/10967494.2019.1592793

26. Orayo, J..ङ Mose G.. (2016). "A Comparative Study on Contribution of Governance on Economic growth Countries in the East African". International Journal of Regional Development, 2016, Vol.3, No.2 ISSN 2373-9851.

27. Reyna, Oscar,. (2007)."Panel Data Analysis Fixed and Random Effects using Stata (v. 4.2) Princeton University.

28. Romer, David. (2012)."Advanced Microeconomics", Fourth Edition, University of California, Berkeley, The MCgraw-Hill Irwin Company, USA, 2912.

29. Rothstein, B. (2011) "Anti-corruption: The indirect 'big bang' approach", Review of International Political Economy, 18(2):228-250.

30. Salahodjaev, R. (2015). Democracy and economic growth: The role of intelligence in cross-country regressions. Intelligence, 50, 228-234. https://doi.org/10.1016/j.intell.2015.04.013

31. Sen, K. (2016)."Governance, politics and growth". GSDRC Professional Development Reading Pack no. 48. Birmingham, UK: University of Birmingham

32. Siegle, J. (2006). "Democratic Divergence in Africa: Lessons and Implications for Aid". Potsdam, Germany. Source: International Political Science Review

33. Way, Lucan. (2012a). "The sources of authoritarian control after the Cold War: East Africa and the former Soviet Union. Post-Soviet Affairs 28 (4): 424-448.

34. World Development Indicator, (2019)."The Worldwide Governance Indicators: methodology and Analytical issues", the World Bank group. Http://info.worldbank.org/governance/wgi/\#doc 